\title{
PENGARUH RATA-RATA LAMA SEKOLAH DAN PERTUMBUHAN EKONOMI SERTA PENYERAPAN TENAGA KERJA TERHADAP PERSENTASE PENDUDUK MISKIN
}

\author{
Muhamad Arif $\mathbf{W}^{\mathrm{a}}$ \\ Siti Umajah Masjkuri ${ }^{b}$ \\ ${ }^{a}$ Sekolah Pascasarjana Universitas Airlangga ${ }^{b}$ Fakultas Ekonomi dan Bisnis Universitas Airlangga \\ Email:warifmuhammad62@gmail.com ${ }^{\text {a }}$; sitimasjkuri@gmail.com ${ }^{\text {b }}$
}

\section{ARTICLE HISTORY}

Received:

1 Februari 2018

Revised

9 March 2018

Accepted:

26 March 2018

Online available:

30 Mei 2018

Keywords (Calibri 10):

Path analysis,

poverty,

employment

Kata Kunci:

Path analysis,

kemiskinan,

penyerapan tenaga

kerja

The keywords should be avoiding general and plural terms and multiple concepts. Keywords should not more than 5 words or phrases in alphabetical order.

\begin{abstract}
Introduction: East Java is one of the provinces with good economic performance: high economic growth accompanied by increased employment, increased average length of schooling, and decreased poverty. However, the poverty rate in East Java is still relatively high. This study aims to examine and analyze the effect of the average length of schooling, economic growth, and labor absorption on the percentage of poor people in districts and cities in East Java in 2007-2011.

Methods: This study uses the path analysis method. This method was chosen because it is able to explain the direct and indirect effects between the independent variables and between the independent variables and the dependent variable based on a model built from previous theory and research.

Results: The results showed that the average length of schooling had a negative effect on labor absorption, labor absorption had a positive effect on the percentage of poor people, so that the average length of schooling had an indirect negative effect on the percentage of poor people through labor absorption. Economic growth has a direct positive effect on labor absorption and indirectly on the percentage of poor people, but has a direct negative effect on the percentage of poor people.

Conclusion and suggestion: It is necessary to map the quality and specifications of education required by employment. The link and match program between the world of work and education needs to be reconsidered, not only in higher education but also at secondary level education.
\end{abstract}




\begin{abstract}
ABSTRAK
Jawa Timur adalah salah satu provinsi berkinerja ekonomi bagus: pertumbuhan ekonomi tinggi disertai peningkatan penyerapan tenaga kerja, peningkatan rata-rata lama sekolah, dan penurunan kemiskinan. Meskipun demikian, tingkat kemiskinan Jawa Timur masih relatif tinggi. Selama 2007-2012, persentase penduduk miskin Jawa Timur selalu di atas nasional. IPM Jawa Timur juga lebih rendah daripada IPM nasional. Di antara provinsi-provinsi di Jawa, IPM Jawa Timur hanya lebih baik daripada IPM Banten. Berdasarkan latar belakang tersebut penelitian ini bertujuan menguji dan menganalisis pengaruh rata-rata lama sekolah, pertumbuhan ekonomi, dan penyerapan tenaga kerja terhadap persentase penduduk miskin kabupaten dan kota di Jawa Timur tahun 20072011 dengan menggunakan metode path analysis. Metode ini dipilih karena mampu menjelaskan pengaruh langsung dan tidak langsung antarvariabel bebas maupun antara variabel-variabel bebas dengan variabel terikat berdasarkan model yang dibangun dari teori maupun penelitian sebelumnya. Hasil penelitian menunjukkan bahwa rata-rata lama sekolah berpengaruh negatif terhadap penyerapan tenaga kerja, penyerapan tenaga kerja berpengaruh positif terhadap persentase penduduk miskin, sehingga ratarata lama sekolah berpengaruh negatif secara tidak langsung terhadap persentase penduduk miskin melalui penyerapan tenaga kerja. Pertumbuhan ekonomi berpengaruh positif secara langsung terhadap penyerapan tenaga kerja dan secara tidak langsung terhadap persentase penduduk miskin, tetapi berpengaruh negatif secara langsung terhadap persentase penduduk miskin.
\end{abstract}

\title{
INTRODUCTION
}

Jawa Timur merupakan salah satu provinsi dengan tingkat pertumbuhan ekonomi yang cukup tinggi di Indonesia. Pada tahun 2012 ekonomi JawaTimur tumbuh 7,27\% dan menyumbang $14,89 \%$ dari perekonomian nasional. Di antara provinsi-provinsi lain di Pulau Jawa, Jawa Timur memiliki pertumbuhan ekonomi yang tergolong tinggi, bahkan mencatat pertumbuhan PDRB tertinggi selama tiga tahun terakhir ini $(2010-2012)$ dan mengalahkan DKI Jakarta yang secara tradisional dikenal sebagai pusat perekonomian Indonesia.

Tingginya pertumbuhan ekonomi diharapkan mampu menjadi pertumbuhan ekonomi yang inklusif dan mampu mengurangi kemiskinan. Kontribusi pertumbuhan ekonomi terhadap penanggulangan kemiskinan dapat diukur dengan elastisitas pertumbuhan ekonomi terhadap kemiskinan atau growth elasticity of poverty (GEP). GEP menunjukkan perubahan persentase ukuran kemiskinan pada setiap 1 persen pertumbuhan ekonomi (Stöterau, 2010:3). Sebagaimana terlihat pada Tabel 1, sejak tahun 2010 nilai GEP Jawa Timur turun drastis. Jika pada tahun 2009 nilai GEP Jawa Timur sebesar 2,1, maka pada tahun 2010 dan 2011 hanya sebesar 0,72 dan 0,88 persen. 
Hal ini berarti kontribusi pertumbuhan ekonomi dalam mengurangi kemiskinan semakin mengecil.

Tabel 1

Nilai GEP Provinsi Jawa Timur Tahun 2007 - 2011

\begin{tabular}{cccc}
\hline Tahun & Penurunan Kemiskinan (\%) & Pertumbuhan PDRB (\%) & GEP** \\
\hline 2007 & 6,81 & 6,11 & 1,12 \\
2008 & 8,46 & 5,94 & 1,42 \\
2009 & 10,51 & 5,01 & 2,10 \\
2010 & 4,80 & 6,68 & 0,72 \\
2011 & 6,32 & 7,22 & 0,88 \\
\hline
\end{tabular}

Sumber: BPS, diolah.

*) Penurunan kemiskinan: persentase penurunan jumlah penduduk miskin dibanding tahun sebelumnya **) GEP = rasio penurunan kemiskinan terhadap pertumbuhan PDRB

Dibandingkan dengan tingkat kemiskinan secara nasional, tingkat kemiskinan di Jawa Timur masih tergolong relatif tinggi. Persentase penduduk miskin di Jawa Timur memang mengalami penurunan dari tahun ke tahun, mulai dari 19,98\% pada Maret 2007 menjadi $13,40 \%$ pada Maret 2012. Akan tetapi selama periode tersebut persentase penduduk miskin Jawa Timur masih lebih tinggi daripada persentase penduduk miskin nasional yang terus menurun dari 16,58\% pada Maret 2007 menjadi 11,96\% pada Maret 2012 (BPS).

Tingkat kemiskinan berhubungan dengan kualitas pendidikan. Tingkat kemiskinan yang tinggi seringkali disertai kualitas pendidikan yang buruk. Salah satu indikator kualitas pendidikan di suatu wilayah adalah rata-rata lama sekolah. Semakin besar ratarata lama sekolah dapat dikatakan bahwa kualitas pendidikan semakin meningkat. Di daerah dengan tingkat kemiskinan tinggi, kualitas pendidikan penduduk juga relatif rendah. Kabupaten Sampang, Bangkalan, Probolinggo, Sumenep, dan Bondowoso merupakan daerah dengan rata-rata lama sekolah terendah di Jawa Timur. Hal ini ditunjukkan oleh rendahnya rata-rata lama sekolah di daerah tersebut yang lama waktunya antara dari tahun 2007-2011 hanya hanya berkisar antara 3,8 - 5,7 tahun. Tingkat kemiskinan di daerah-daerah tersebut relatif tinggi yaitu berkisar antara $20,94 \%$ $39,42 \%$. Sementara di daerah lain rata-rata lama sekolah mencapai 6 tahun atau lebih. Daerah dengan rata-rata lama sekolah terlama antara lain adalah Kota Batu, Kota Malang, Kota Madiun, Kota Surabaya, dan Kota Mojokerto. Di daerah-daerah tersebut rata-rata lama sekolah mencapai 9,7 - 11,1 tahun selama tahun 2007-2011.

Rata-rata lama sekolah seluruh Jawa Timur dan masing-masing kabupaten/kota terus meningkat dari tahun ke tahun. Data BPS (2011) menunjukkan bahwa rata-rata lama sekolah Jawa Timur mengalami peningkatan dari 7,2 tahun pada tahun 2007 menjadi 7,6 tahun pada tahun 2011. Idealnya rata-rata lama sekolah yang semakin meningkat ini disertai dengan tingkat pengurangan kemiskinan yang juga semakin membaik. Namun, tingkat pengurangan kemiskinan Jawa Timur selama tahun 2007 
sampai dengan 2011 cenderung menurun. Perkembangan rata-rata lama sekolah dan penurunan jumlah penduduk miskin dapat dilihat pada Tabel 2.

Tabel 2

Perkembangan Rata-Rata Lama Sekolah dan

Penurunan Jumlah Penduduk Miskin Jawa Timur

\begin{tabular}{ccc}
\hline \multirow{2}{*}{ Tahun } & Rata-Rata Lama Sekolah (Tahun) & Penurunan Jumlah Penduduk Miskin (\%) \\
\hline 2007 & 7,2 & 6,8 \\
2008 & 7,2 & 8,5 \\
2009 & 7,4 & 10,5 \\
2010 & 7,5 & 4,8 \\
2011 & 7,6 & 6,3 \\
\hline
\end{tabular}

Sumber: BPS (2011), diolah

*) Penurunan kemiskinan: persentase penurunan jumlah penduduk miskin dibanding tahun sebelumnya

Berdasarkan hal tersebut di atas, perlu dilakukan penelitian mengenai pengaruh rata-rata lama sekolah, pertumbuhan ekonomi, dan penyerapan tenaga kerja terhadap persentase penduduk miskin di Jawa Timur selama tahun 2007-2011.

\section{LITERATURE REVIEW}

\section{The traditional society}

Todaro dan Smith (2006:264) mengemukakan beberapa pendapat yang sering muncul di kalangan pembuat kebijakan bahwa pengurangan kemiskinan akan memperlambat pertumbuhan ekonomi. Pendapat ini disangkal oleh Todaro dan Smith dengan mengemukakan beberapa alasan mengapa kebijakan yang ditujukan untuk mengurangi kemiskinan tidak harus memperlambat laju pertumbuhan. Pertama, kemiskinan yang meluas menciptakan kondisi yang membuat kaum miskin tidak mempunyai akses terhadap pinjaman kredit, tidak mampu membiayai pendidikan anaknya, dan mempunyai banyak anak sebagai sumber keamanan keuangan di masa tuanya nanti. Faktor-faktor ini secara bersama-sama menyebabkan pertumbuhan per kapita lebih kecil daripada jika distribusi pendapatan lebih merata. Kedua, data empiris menunjukkan bahwa kaum kaya di negara-negara miskin sekarang tidak lagi gemar menginvestasikan bagian yang besar dari pendapatan mereka di dalam perekonomian negara mereka sendiri. Ketiga, pendapatan rendah dan standar hidup buruk yang dialami golongan miskin dapat menurunkan produktifitas ekonomi yang berakibat secara langsung atau tak langsung pada perlambatan pertumbuhan ekonomi. Keempat, peningkatan pendapatan golongan miskin akan mendorong kenaikan permintaan produk kebutuhan rumah tangga buatan lokal, seperti makanan dan pakaian, sementara golongan kaya akan membelanjakan sebagian besar pendapatannya untuk barangbarang mewah impor. Meningkatnya permintaan produk-produk lokal memberikan rangsangan yang lebih besar kepada produksi lokal, memperbesar kesempatan kerja 
lokal, dan menumbuhkan investasi lokal. Kelima, keterkaitan penurunan kemiskinan dan ekspansi ekonomi. Penurunan kemiskinan secara massal dapat merangsang ekspansi ekonomi yang lebih sehat karena merupakan insentif materi dan psikologis yang kuat bagi meluasnya partisipasi publik di dalam proses pembangunan.

Menurut Nallari dan Griffith (2011:64) pertumbuhan yang berkelanjutan akan mengurangi kemiskinan. Pertumbuhan dihasilkan dari input ekonomi (modal dan tenaga kerja) serta efisiensi penggunaan input tersebut. Karena penambahan input secara terus menerus pada akhirnya tidak menambah pertumbuhan maka diperlukan faktor lain untuk mempertahankan pertumbuhan. Faktor lain tersebut diperoleh melalui perkembangan teknologi, perbaikan manajemen, dan peningkatan keterampilan melalui pendidikan. Agar pertumbuhan dapat efektif mengurangi kemiskinan, maka tingkat produktifitas suatu negara harus ditingkatkan. Komposisi pertumbuhan ekonomi juga berpengaruh terhadap pengurangan kemiskinan. Komposisi sektoral pertumbuhan ekonomi dapat menjelaskan mengapa pada laju pertumbuhan yang sama tingkat pengurangan kemiskinan yang dihasilkan berbeda-beda. Pertumbuhan yang dihasilkan dari penggunaan secara massal tenaga kerja tak terlatih akan memberikan dampak pengurangan kemiskinan secara lebih cepat dan besar daripada pertumbuhan yang dihasilkan dari penggunaan tenaga kerja terdidik. Hal ini karena sebagian besar orang miskin merupakan tenaga kerja tak terdidik. Tingkat ketimpangan ekonomi masyarakat serta bagaimana ketimpangan tersebut berubah di sepanjang waktu juga menjadi faktor penting yang menentukan sejauh mana kemiskinan akan dipengaruhi oleh pertumbuhan ekonomi.

Pasar tenaga kerja adalah salah satu saluran utama bagi pertumbuhan ekonomi untuk membantu mengurangi kemiskinan. Pertumbuhan ekonomi dihasilkan oleh tenaga kerja dan produktifitas tenaga kerja. Di lain pihak, kegagalan menerjemahkan pertumbuhan ekonomi menjadi kesempatan kerja dapat mengganggu upaya pengurangan kemiskinan. Tenaga kerja adalah aset utama penduduk miskin. Lapangan kerja adalah jalan keluar dari kemiskinan (Nallari dan Griffith, 2011: 269).

Secara konseptual, hubungan antara pertumbuhan, ketenagakerjaan, dan kemiskinan dapat dianalisis pada tingkat makro maupun mikro. Pada tingkat makro, hubungan tersebut dapat dianalisis melalui produktifitas tenaga kerja sebagaimana ditunjukkan oleh tingkat upah atau penghasilan yang rendah. Sedangkan pada tingkat mikro, hubungan tersebut dapat dianalisis melalui rendahnya kualitas SDM serta terbatasnya partisipasi anggota keluarga dalam dunia kerja (Islam, 2004). Untuk mengetahui dinamika hubungan antara pertumbuhan ekonomi, ketenagakerjaan, dan pengurangan kemiskinan dapat digunakan ukuran elastisitas ketenagakerjaan (employment elasticity). Elastisitas ketenagakerjaan mengukur perubahan jumlah tenaga 
kerja dalam suatu wilayah dibandingkan dengan pertumbuhan output ekonomi (PDB). Dengan menganalisis pertumbuhan output dan elastisitas ketenagakerjaan, dapat diketahui apakah pertumbuhan ekonomi menambah jumlah tenaga kerja atau meningkatkan produktifitas tenaga kerja serta sejauh mana keseimbangan antara keduanya (jumlah dan produktifitas tenaga kerja). Pertumbuhan ekonomi positif disertai elastisitas ketenagakerjaan lebih dari satu menunjukkan penurunan produktifitas tenaga kerja dan peningkatan jumlah pekerjaan yang berproduktifitas rendah. Dalam perspektif pembangunan dan upaya pengurangan kemiskinan, terjadi perselisihan mengenai pertumbuhan seperti apa yang lebih bermanfaat: pertumbuhan yang menambah jumlah tenaga kerja ataukah pertumbuhan yang meningkatkan produktifitas (Nallari dan Griffith, 2011: 275). Akan tetapi, Islam (2008), sebagaimana diuraikan sebelumnya, menunjukkan bahwa kedua aspek tersebut (employment with rising productivity) harus diraih agar upaya pengurangan kemiskinan berhasil.

\section{Previous Study}

Beberapa penelitian sebelumnya telah membahas masalah pertumbuhan ekonomi, penyerapan tenaga kerja, pendidikan, dan kemiskinan. Balisacan dan Fuwa (2004) menganalisis proses pertumbuhan ekonomi dan pengurangan kemiskinan di Filipina dengan menggunakan model pertumbuhan neoklasik dan data ekonomi di tingkat provinsi. Kinerja pertumbuhan ekonomi dan pengurangan kemiskinan di Filipina selama tahun 1965-1995 relatif lebih buruk dibanding negara-negara tetangga di Asia Tenggara. Peneliti menganalisis apakah hal ini akibat lambatnya respon penurunan kemiskinan terhadap pertumbuhan ekonomi, tingginya ketimpangan pendapatan, atau kebijakan politik ekonomi yang tidak tepat. Hasil penelitian menunjukkan bahwa rendahnya respon pengurangan kemiskinan terhadap pertumbuhan ekonomi adalah akibat rendahnya pertumbuhan di sektor pertanian. Hal ini mengingat pertanian merupakan sektor yang paling banyak menyerap tenaga kerja dibanding sektor industri.

Donaldson (2008) meneliti respon pengurangan kemiskinan terhadap pertumbuhan ekonomi. Berangkat dari kesimpulan umum bahwa pertumbuhan ekonomi berkontribusi positif terhadap pengurangan kemiskinan, penelitian ini membahas kasuskasus khusus respon pengurangan kemiskinan terhadap pertumbuhan ekonomi yang berbeda dari perkiraan. Respon dibagi menjadi dua golongan, yaitu perkecualian negatif dan perkecualian positif. Perkecualian negatif apabila tingkat pengurangan kemiskinan akibat pertumbuhan ekonomi berada di bawah nilai yang diharapkan dan perkecualian positif apabila di atas nilai yang diharapkan. Penelitian ini menyimpulkan adanya faktorfaktor lain yang menyertai pertumbuhan ekonomi dalam mendorong pengurangan kemiskinan.

Ferreira dkk. (2010) meneliti faktor-faktor penyebab rendahnya kontribusi pertumbuhan ekonomi dalam menurunkan kemiskinan di Brasil. Selama periode 1985- 
2004, tingkat kemiskinan di Brasil hanya turun dari 33\% menjadi 29\%, sementara di negara berkembang lainnya turun drastis dari 33\% menjadi $18 \%$. Dengan membagi agregat PDB ke dalam beberapa wilayah dan sektor, penelitian ini menemukan bahwa efektifitas pertumbuhan ekonomi dalam menurunkan kemiskinan bervariasi di berbagai sektor, wilayah, dan waktu. Pertumbuhan sektor jasa ternyata lebih menurunkan kemiskinan dibandingkan sektor pertanian dan industri. Efektifitas pertumbuhan di sektor industri dalam menurunkan kemiskinan bervariasi menurut wilayah dan variasi ini berhubungan dengan kualitas SDM masing-masing wilayah. Penelitian ini juga menyimpulkan bahwa pada saat pertumbuhan ekonomi rendah dan stagnan, intervensi kebijakan pemerintah dalam bentuk jaminan sosial sangat efektif dalam menurunkan tingkat kemiskinan.

Zaman dan Khilji (2013) menguji dan membuat model hubungan antara pertumbuhan ekonomi dan kemiskinan di Pakistan selama tahun 2011-2035. Analisis dekomposisi varian dan respon impuls digunakan dalam penelitian ini untuk menguji hubungan kausalitas antara kemiskinan (rasio head count, poverty gap, dan squared poverty gap), pertumbuhan ekonomi (rata-rata pendapatan rumah tangga, nilai tambah industri, dan nilai tambah pertanian), dan ketimpangan pendapatan untuk melihat apakah pertumbuhan pendapatan dan ukuran-ukuran kemiskinan dapat saling menjelaskan satu sama lain. Hasil analisis menunjukkan bahwa pertumbuhan ekonomi, ukuran-ukuran kemiskinan, dan tingkat ketimpangan pendapatan saling berpengaruh satu sama lain.

Bonal (2007) meneliti kegagalan pendidikan dalam mengurangi tingkat kemiskinan di negara-negara Amerika Latin. Hasil analisis menyimpulkan bahwa kegagalan ini kurang lebih karena strategi pendidikan mengabaikan tiga hal penting. Pertama, tingkat kemiskinan sasaran kebijakan pendidikan. Kedua, peran pendidikan dalam menciptakan kohesi sosial. Ketiga, kondisi kemampuan sasaran kebijakan pendidikan dalam menempuh pendidikan.

Kuepie dkk. (2009) mengestimasi tingkat imbal hasil pendidikan di tujuh pusat perekonomian di Afrika Barat (Abidjan, Bamako, Cotonou, Dakar, Lome, Niamey dan Ouagadougou) melalui serangkaian survei terhadap kelompok tenaga kerja di sektor pemerintahan, swasta formal, dan informal. Hasil penelitian menunjukkan bahwa pendidikan berpengaruh positif terhadap tingkat penghasilan kelompok-kelompok pekerja tersebut. Secara berurutan pengaruh paling besar didapat pada kelompok pekerja di sektor pemerintahan, diikuti sektor swasta formal dan sektor informal.

Rolleston (2011) meneliti pengaruh pendidikan terhadap kesejahteraan dan kemiskinan dan sebaliknya, pengaruh kesejahteraan dan aspek-aspek ekonomi lainnya dalam menentukan tingkat pendidikan di Ghana selama tahun 1991-2006. Hasil 
penelitian menunjukkan bahwa tingkat pendidikan memainkan peranan penting dalam menentukan tingkat kesejahteraan rumah tangga dan bahwa tingkat pendidikan yang lebih tinggi akan memberikan manfaat yang lebih tinggi juga.

Gounder dan Xing (2012) menyajikan permodelan ekonomi dengan menggunakan data Pendapatan Rumah Tangga Fiji dan Survei Pengeluaran Tahun 2002/2003 untuk menguji faktor-faktor ekonomi dan sosial yang krusial untuk mengurangi kemiskinan. Penelitian ini meneliti aspek moneter dan nonmoneter dari pendidikan dan kesehatan. Penelitian terhadap aspek moneter menunjukkan bahwa semua rumah tangga (dengan berbagai tingkat pendapatan) mendapatkan manfaat berupa tambahan keterampilan melalui pendidikan formal. Akan tetapi pendidikan formal ini tidak dapat mencegah orang yang hanya berpendidikan dasar jatuh ke dalam kemiskinan. Sementara model non-moneter menunjukkan bahwa pendidikan berpengaruh positif terhadap kecenderungan orang untuk menjaga kesehatan dan mendapat fasilitas perumahan yang baik.

Cremin dan Nakabuko (2012) meneliti manfaat investasi pendidikan dalam mengurangi kemiskinan dan kondisi-kondisi yang mendorong atau menghambat kontribusi pendidikan terhadap pengurangan kemiskinan. Hasil penelitian menunjukkan bahwa investasi pendidikan sangat berpengaruh terhadap peningkatan output per kapita pekerja dan mampu mengurangi kemiskinan.

Jalil dan Idrees (2013) mengevaluasi pengaruh pendidikan terhadap pertumbuhan ekonomi Pakistan selama tahun 1960 - 2010. Penelitian ini mendukung hipotesis bahwa investasi pada sektor pendidikan dapat meningkatkan pertumbuhan ekonomi suatu negara.

Herman dan Georgescu (2012) meneliti strategi ketenagakerjaan dan pendidikan di Romania. Hasil penelitian ini menunjukkan bahwa peningkatan partisipasi pada pelatihan kejuruan sangat penting untuk mendukung peningkatan kualitas tenaga kerja. Strategi ini mampu meningkatkan kemampuan tenaga kerja dalam mengadopsi permintaan-permintaan baru di dunia kerja, menurunkan tingkat pengangguran, dan mengurangi kemiskinan. Keberhasilan pelatihan kejuruan yang mendorong pertumbuhan lapangan kerja dan pengurangan kemiskinan hanya dapat dicapai dengan mengadopsi dan menerapkan kebijakan ketenagakerjaan yang sesuai dengan kondisi ekonomi eksternal dan internal sebelum, selama, dan setelah proses pelatihan berlangsung.

Dorantes dan Padial (2010) yang meneliti pengaruh lapangan pekerjaan sementara terhadap kemiskinan di Spanyol. Hasil penelitian menunjukkan bahwa pekerjaan sementara, terutama bagi perempuan, sangat rentan menyebabkan seseorang jatuh dalam kemiskinan. 
Bangwayo-Skeete dkk. (2011) menguji peran pendidikan formal maupun informal dalam menciptakan sikap mental positif yang mendukung usaha pencapaian tujuantujuan ekonomi. Sebagaimana diketahui bahwa nilai-nilai budaya sangat berpengaruh terhadap pertumbuhan ekonomi. Berdasarkan data World Values Survey dari 43 negara, hasil penelitian menunjukkan bahwa orang-orang dengan tingkat pendidikan dan akses media yang lebih tinggi akan lebih mampu menerima nilai-nilai yang mendukung pencapaian ekonomi daripada mereka yang hanya mengikuti pandangan-pandangan tradisional. Penelitian ini menunjukkan pengaruh tak langsung pendidikan terhadap pertumbuhan ekonomi.

Ganegodage dan Rambaldi (2011) mengevaluasi kontribusi investasi pendidikan terhadap pertumbuhan ekonomi Sri Lanka selama tahun 1959-2008. Modal fisik, perubahan kebijakan ekonomi, dan faktor etnis juga dievaluasi dalam penelitian ini karena juga memainkan peranan yang cukup penting. Penelitian ini menggunakan kerangka kerja model pertumbuhan neoklasik dan endogen. Pengaruh pendidikan diteliti melalui pengukuran kualitas SDM. Imbal hasil pendidikan bernilai positif tetapi lebih rendah dibandingkan negara-negara berkembang lainnya. Tidak seperti sebagian besar negara maju, tingginya imbal hasil investasi fisik tidak begitu berpengaruh terhadap pertumbuhan ekonomi. Perang berpengaruh negatif terhadap output ekonomi. Pengaruh perubahan kebijakan ekonomi tidak dapat disimpulkan dengan meyakinkan. Hasil penelitian ini menunjukkan perlunya strategi yang tepat untuk mengalokasikan sumbur daya di bidang pendidikan agar imbal hasilnya dapat ditingkatkan.

Penelitian ini merupakan pengembangan terhadap beberapa penelitian di atas. Penelitian di atas sebagian besar hanya menitikberatkan hubungan satu variabel bebas dengan satu variabel terikat. Cremin dan Nakabuko (2012) meneliti pengaruh pendidikan terhadap pengurangan kemiskinan, meskipun dalam analisis teoretis mereka membahas aspek ketenagakerjaan sebagai faktor yang menghubungkan antara pendidikan dan kemiskinan.

Bangwayo-Skeete dkk. (2011) meneliti pengaruh satu variabel, yaitu pendidikan, terhadap pertumbuhan ekonomi. Manfaat pendidikan berupa sikap mental positif yang mendukung pertumbuhan ekonomi hanya menjadi variabel laten yang tidak diukur dan dihitung dalam penelitian mereka. Kuepie dkk. (2009) hanya meneliti pengaruh pendidikan terhadap tingkat pendapatan tenaga kerja. Hanya Gounder dan Xing (2012) yang meneliti pengaruh pendidikan dan kesehatan terhadap kemiskinan. Berdasarkan teori-teori yang telah dibahas sebelumnya, penelitian ini mengembangkan penelitian terdahulu dengan menghubungkan dan mengukur variabel pendidikan, penyerapan tenaga kerja, dan pertumbuhan ekonomi dalam mempengaruhi kemiskinan.i ikan. Inefisiensi terjadi karena terlampauinya jumlah produksi lestari sehingga peningkatan upaya penangkapan tidak disertai dengan peningkatan jumlah hasil tangkapan.

Published by University of Airlangga.

This is an open access article under the CC BY license (https://creativecommons.org/licenses/by-sa/4.0/) 


\section{RESEARCH METHODS}

Data yang digunakan dalam penelitian ini adalah data sekunder rata-rata lama sekolah, pertumbuhan ekonomi, persentase penyerapan tenaga kerja, dan persentase penduduk miskin yang diperoleh dari Badan Pusat Statistik (BPS) Provinsi Jawa Timur maupun BPS Pusat. Seluruh data tersebut merupakan data kabupaten dan kota di Jawa Timur tahun 2007 - 2011. Pertumbuhan Ekonomi adalah pertumbuhan Produk Domestik Regional Bruto (PDRB) atas dasar harga konstan tahun 2000 yang dinyatakan dalam satuan persen. Penyerapan tenaga kerja adalah rasio jumlah penduduk berumur 15 tahun ke atas yang bekerja terhadap jumlah angkatan kerja, dinyatakan dalam satuan persen. Persentase penduduk miskin adalah rasio jumlah penduduk yang berada di bawah garis kemiskinan terhadap jumlah penduduk secara keseluruhan, dinyatakan dalam satuan persen. Rata-rata lama sekolah adalah jumlah tahun belajar penduduk usia 15 tahun ke atas yang telah diselesaikan dalam Pendidikan Formal, dinyatakan dalam angka konversi dengan satuan tahun.

Metode analisis yang digunakan adalah analisis jalur (path analysis). Analisis jalur digunakan untuk mengetahui hubungan langsung maupun tak langsung antara variabelvariabel bebas dengan variabel terikat. Persamaan struktural yang didapat dari diagram jalur di atas adalah :

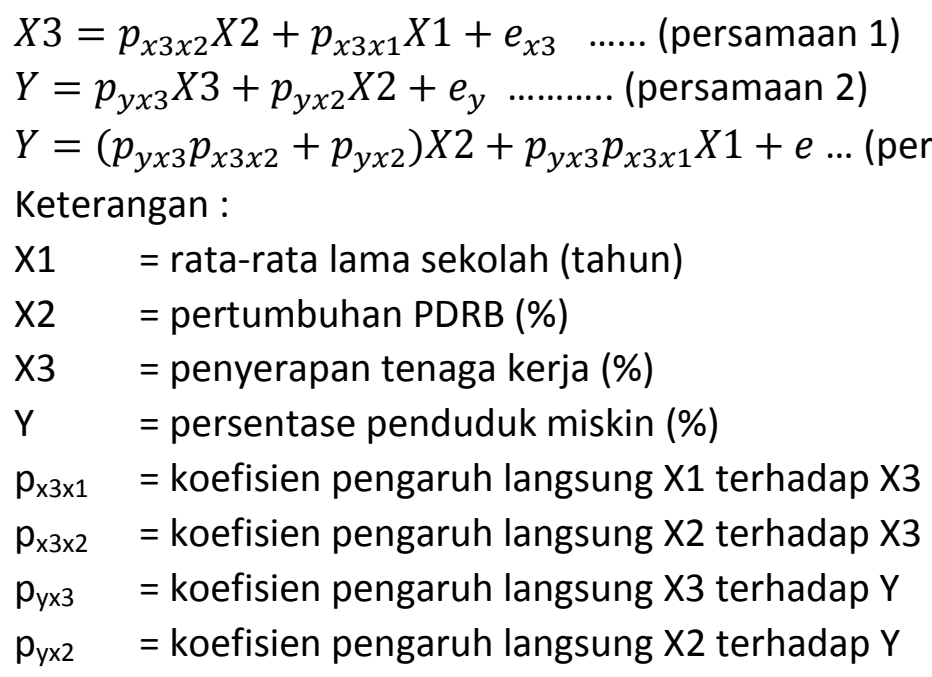

\section{RESULT AND ANALYSIS}

Analisis pertama yang dilakukan dalam penelitian ini adalah penentuan koefisien pengaruh antarvariabel, baik pengaruh langsung maupun tak langsung. Pengaruh langsung yang diukur adalah pengaruh variabel rata-rata lama sekolah $(x 1)$ terhadap penyerapan tenaga kerja $(x 3)$, pengaruh variabel pertumbuhan ekonomi $(x 2)$ terhadap variabel penyerapan tenaga kerja $(x 3)$ dan variabel persentase penduduk miskin $(y)$, dan pengaruh variabel penyerapan tenaga kerja $(x 3)$ terhadap variabel persentase penduduk miskin (y). Adapun pengaruh tidak langsung yang diukur adalah pengaruh variabel ratarata lama sekolah $(x 1)$ terhadap variabel persentase penduduk miskin (y) melalui variabel 
penyerapan tenaga kerja (x3) dan pengaruh variabel pertumbuhan ekonomi (x2) terhadap variabel persentase penduduk miskin melalui variabel penyerapan tenaga kerja (x3).

Tabel 3

Hasil Uji Statistik Hubungan Langsung Antarvariabel

\begin{tabular}{ccccc}
\hline Pengaruh & Koefisien & P & Kriteria Uji & Hasil Uji \\
\hline x1 terhadap x3 & -0.673 & .000 & $\mathrm{P}<\alpha$ & Ho ditolak, pengaruh signifikan \\
x2 terhadap x3 & 0.167 & .001 & $\mathrm{P}>\alpha$ & Ho ditolak, pengaruh signifikan \\
x3 terhadap y & 0.418 & .000 & $\mathrm{P}<\alpha$ & Ho ditolak, pengaruh signifikan \\
x2 terhadap y & -0.263 & .000 & $\mathrm{P}<\alpha$ & Ho ditolak, pengaruh signifikan \\
\hline
\end{tabular}

Sumber: Data Diolah (Eviews)

Tabel 4.

Koefisien Pengaruh Tak Langsung dan Akhir Antarvariabel

\begin{tabular}{|c|c|c|c|}
\hline & $x 2$ & $\mathrm{x} 1$ & $x 3$ \\
\hline \multicolumn{4}{|c|}{ Koefisien Pengaruh Tak Langsung Antarvariabel } \\
\hline$x 3$ & .000 & .000 & .000 \\
\hline y & .070 & -.282 & .000 \\
\hline \multicolumn{4}{|c|}{ Koefisien Pengaruh Akhir Antarvariabel } \\
\hline x3 & .167 & -.673 & .000 \\
\hline y & -.193 & -.282 & .418 \\
\hline
\end{tabular}

Sumber: Data Diolah (Eviews)

\section{Pengaruh Rata-rata Lama Sekolah Terhadap Penyerapan Tenaga Kerja}

Hasil analisis statistik menunjukkan bahwa rata-rata lama sekolah berpengaruh signifikan secara langsung terhadap penyerapan tenaga kerja dengan koefisien pengaruh sebesar -0,673. Angka ini menunjukkan rata-rata lama sekolah berpengaruh negatif atau berbanding terbalik terhadap penyerapan tenaga kerja. Artinya semakin tinggi rata-rata lama sekolah, semakin rendah penyerapan tenaga kerja. Semakin rendah rata-rata lama sekolah, justeru penyerapan tenaga kerja semakin besar.

Hasil analisis tersebut memperkuat fakta empiris yang ditampilkan oleh data statistik. Daerah-daerah yang memiliki rata-rata lama sekolah rendah, tingkat penyerapan tenaga kerjanya justru tergolong sangat tinggi. Rata-rata lama sekolah daerah-daerah tersebut selama tahun 2007-2011 adalah hanya berkisar antara 3,8 - 5,7 tahun, sementara tingkat penyerapan tenaga kerjanya sangat tinggi berkisar antara 92,1 - 98,4 persen. Sebaliknya daerah-daerah dengan rata-rata lama sekolah tinggi justru memiliki tingkat penyerapan kerja yang relatif rendah. Rata-rata lama sekolah daerahdaerah tersebut selama tahun 2007-2011 adalah mencapai kisaran 9,6 - 11,1 tahun, sementara tingkat penyerapan tenaga kerjanya relatif rendah berkisar antara 84,5-95,1 persen. 
Temuan ini bertolak belakang dengan teori Adam Smith (1776) dalam Berg (2005: 372) yang menyatakan bahwa pendidikan merupakan eksternalitas positif bagi perekonomian dengan cara membentuk tenaga kerja terdidik. Hanushek dan Wößmann (2007:4) juga menyatakan bahwa dalam sebuah sistem perekonomian, pendidikan dapat meningkatkan kualitas SDM tenaga kerja, menambah produktifitas tenaga kerja, dan pada akhirnya meningkatkan pertumbuhan ekonomi. Tenaga kerja yang berkualitas dan berproduktifitas tinggi tentu akan lebih mudah diserap oleh lapangan pekerjaan yang tersedia.

Tingkat penyerapan tenaga kerja dipengaruhi oleh kontribusi sektor perekonomian terhadap Pendapatan Regional Bruto (PDRB) kabupaten/kota di Jawa Timur. Selama tahun 2007 - 2011, daerah dengan rata-rata lama sekolah rendah dan tingkat penyerapan tenaga kerja relatif tinggi seperti Kabupaten Sampang, Kabupaten Bangkalan, Kabupaten Probolinggo, Kabupaten Sumenep, dan Kabupaten Bondowoso memiliki PDRB dengan kontribusi sektor pertanian yang relatif tinggi. Sementara pada daerah dengan rata-rata lama sekolah tinggi dan tingkat penyerapan tenaga kerja relatif rendah seperti Kota Mojokerto, Kota Surabaya, Kota Kediri, Kota Madiun, dan Kota Malang, sektor pertanian memberikan kontribusi yang relatif rendah terhadap PDRB. Perbandingan kontribusi sektor pertanian pada dua kelompok daerah tersebut selama tahun 2007 sampai dengan 2011 dapat dilihat pada Tabel 6 berikut:

Tabel 5

Perbandingan Rata-rata Lama Sekolah, Kontribusi Sektor Pertanian Terhadap PDRB, dan Penyerapan Tenaga Kerja Tahun 2007 - 2011

\begin{tabular}{|l|c|c|c|}
\hline \multicolumn{1}{|c|}{ Kabupaten/Kota } & $\begin{array}{c}\text { Rata-rata Lama } \\
\text { Sekolah (tahun) }\end{array}$ & $\begin{array}{c}\text { Kontribusi Sektor } \\
\text { Pertanian (\%) }\end{array}$ & $\begin{array}{c}\text { Penyerapan } \\
\text { Tenaga Kerja (\%) }\end{array}$ \\
\hline Daerah dengan rata-rata lama sekolah rendah: \\
\hline Kab. Sumenep & $4,9-5,7$ & $49,90-54,05$ & $96,08-98,11$ \\
\hline Kab. Bondowoso & $5,2-5,6$ & $42,33-44,01$ & $96,35-98,41$ \\
\hline Kab. Sampang & $3,8-4,1$ & $40,98-45,20$ & $96,09-98,30$ \\
\hline Kab. Bangkalan & $5,0-5,2$ & $29,87-32,20$ & $92,10-96,09$ \\
\hline Kab. Probolinggo & $5,0-5,6$ & $29,48-30,62$ & $96,52-97,98$ \\
\hline Daerah dengan rata-rata lama sekolah tinggi: \\
\hline Kota Mojokerto & $9,7-10,1$ & $3,44-4,92$ & $87,88-94,14$ \\
\hline Kota Madiun & $10,2-10,5$ & $1,86-2,11$ & $84,55-94,85$ \\
\hline Kota Malang & $10,8-11,1$ & $0,32-0,42$ & $88,73-94,81$ \\
\hline Kota Kediri & $10,2-10,5$ & $0,17-0,20$ & $87,82-95,07$ \\
\hline Kota Surabaya & $9,6-10,4$ & $0,09-0,11$ & $88,16-94,85$ \\
\hline
\end{tabular}

Sumber: BPS (2012a)

Perbandingan data pada Tabel 6 di atas apabila disajikan dalam bentuk grafis dan dengan dilengkapi data dari 38 kabupaten/kota selama 2007-2011 sebagaimana Gambar 4 menunjukkan bahwa semakin tinggi persentase PDRB sektor pertanian, semakin tinggi pula penyerapan tenaga kerja. Untuk dua sektor dominan lainnya, yaitu sektor industri pengolahan dan sektor perdagangan, hotel, dan retoran, kecenderungan yang terjadi adalah sebaliknya. Gambar 4 dan 5 menunjukkan bahwa semakin tinggi kontribusi sektor industri pengolahan dan sektor perdagangan, hotel, dan restoran terhadap pembentukan PDRB suatu kabupaten/kota, semakin rendah tingkat penyerapan tenaga 
kerja. Hal ini menunjukkan sektor pertanian lebih banyak menyerap tenaga kerja dibanding dua sektor utama lainnya.

Perekonomian daerah-daerah yang memiliki rata-rata lama sekolah rendah didominasi oleh sektor pertanian yang relatif tidak membutuhkan tenaga kerja berpendidikan tinggi. Dengan demikian, penyerapan tenaga kerja di daerah tersebut relatif tinggi. Sementara struktur perekonomian di daerah perkotaan yang memiliki ratarata lama sekolah tinggi didominasi oleh sektor perdagangan, hotel, dan restoran. Sektor ini tidak membutuhkan banyak tenaga kerja. Dengan demikian tingkat penyerapan tenaga kerja di daerah-daerah perkotaan relatif rendah.

\section{Pengaruh Penyerapan Tenaga Kerja Terhadap Persentase Penduduk Miskin}

Pada penelitian ini penyerapan tenaga kerja berpengaruh signifikan terhadap jumlah penduduk miskin dengan koefisien pengaruh sebesar 0,418. Angka positif menunjukkan bahwa penyerapan tenaga kerja berbanding lurus dengan persentase penduduk miskin. Semakin tinggi penyerapan tenaga kerja, semakin tinggi pula persentase penduduk miskin. Semakin rendah penyerapan tenaga kerja, semakin rendah pula persentase penduduk miskin.

Temuan ini bertentangan dengan teori yang menyatakan bahwa peningkatan penyerapan tenaga kerja akan mengurangi tingkat kemiskinan. Okun (1962) dalam Arsyad (2010:133) memberikan analisis bahwa salah satu cara mengatasi kemiskinan adalah mengadakan investasi untuk tenaga kerja sebagai cara untuk menurunkan tingkat pengangguran. Nallari dan Griffith (2011:269) juga menyatakan bahwa lapangan kerja adalah jalan keluar dari kemiskinan.

Setidaknya ada dua kemungkinan yang dapat menjelaskan mengapa penyerapan tenaga kerja justru menambah jumlah penduduk miskin. Pertama, jumlah tenaga kerja memang meningkat tetapi pendapatan yang diterima oleh tenaga kerja tidak mampu mengangkat taraf ekonomi mereka sampai di atas garis kemiskinan. Sebagaimana dijelaskan sebelumnya, penyerapan tenaga kerja lebih besar terjadi pada daerah-daerah miskin yang struktur ekonominya didominasi oleh sektor pertanian. Sementara menurut keterangan BPS (2013c), tingkat upah pada sektor pertanian paling rendah bila dibandingkan dua sektor utama lainnya, yaitu sektor industri pengolahan dan sektor perdagangan, hotel, dan restoran. Nilai Tukar Petani (NTP) Jawa Timur yang mencerminkan tingkat kesejahteraan petani dengan mengukur kemampuan tukar produk (komoditas) yang dihasilkan/dijual petani dibandingkan dengan barang/jasa yang dibutuhkan petani baik untuk proses produksi maupun untuk konsumsi rumah tangga cenderung rendah dan berfluktuasi selama tahun 2007 - 2011 (BPS, 2013b) sebagaimana terlihat pada Tabel 7 di bawah ini. NTP yang rendah menunjukkan rendahnya daya beli petani untuk memenuhi kebutuhan hidup sehari-hari dari pendapatan yang diperoleh dari sektor pertanian. Rendahnya NTP ini bisa jadi karena produktifitas sektor pertanian 
yang rendah akibat semakin sempitnya luas lahan yang dapat diolah keluarga petani. Menurut hasil Sensus Pertanian Tahun 2013 yang dilakukan oleh BPS, jumlah lahan pertanian di Jawa Timur pada tahun 2013 rata-rata hanya 0,37 hektar per keluarga petani.

Tabel 6

Nilai Tukar Petani (NTP) Jawa Timur Tahun 2008 - 2011 (2007=100)

\begin{tabular}{lcccc}
\hline \multicolumn{1}{c}{ Uraian } & $\mathbf{2 0 0 8}$ & $\mathbf{2 0 0 9}$ & $\mathbf{2 0 1 0}$ & $\mathbf{2 0 1 1}$ \\
\hline Indeks yang diterima petani (It) & 113,08 & 118,88 & 127,78 & 139,26 \\
Indeks yang dibayar petani (Ib) & 112,57 & 121,04 & 129,40 & 136,99 \\
NTP (It/Ib) & $\mathbf{1 0 0 , 4 7}$ & $\mathbf{9 8 , 1 9}$ & $\mathbf{9 8 , 7 4}$ & $\mathbf{1 0 1 , 6 5}$ \\
\hline
\end{tabular}

Sumber: BPS (2013b)

Perbandingan data penyerapan tenaga kerja per sektor ekponomi dengan data persentase penduduk miskin kabupaten/kota di Jawa Timur selama tahun 2007-2011 juga menunjukkan bahwa peningkatan penyerapan tenaga kerja di sektor pertanian justru memperbesar persentase penduduk miskin. Hal ini berbeda dengan penyerapan tenaga kerja di sektor industri pengolahan dan sektor perdagangan, hotel, dan restoran (PHR). Peningkatan penyerapan tenaga kerja di kedua sektor ini disertai dengan penurunan persentase penduduk miskin. Karena sebagian besar (40 - 64 persen) tenaga kerja di Jawa Timur selama tahun 2007 -2011 terserap di sektor pertanian, maka peningkatan penyerapan tenaga kerja justru menambah angka kemiskinan. Kemungkinan kedua yang menyebabkan peningkatan tenaga kerja justru meningkatkan kemiskinan adalah karena tenaga kerja yang terserap bukan dari kelompok penduduk miskin. Kemungkinan kedua ini sesuai dengan penelitian Messkoub (2008) yang menemukan bahwa apabila lapangan kerja yang tersedia membutuhkan keahlian tinggi yang tidak dimiliki oleh penduduk miskin, maka tentu saja mereka tidak akan mendapat manfaat dari lapangan kerja yang tersedia tersebut.

\section{Pengaruh Rata-rata Lama Sekolah Terhadap Persentase Penduduk Miskin}

Berdasarkan model yang dikembangkan, rata-rata lama sekolah berpengaruh secara tidak langsung terhadap persentase penduduk miskin melalui penyerapan tenaga kerja. Hasil analisis menunjukkan rata-rata lama sekolah berpengaruh tidak langsung secara signifikan terhadap persentase penduduk miskin dengan koefisien pengaruh sebesar -0,282. Angka ini menunjukkan bahwa rata-rata lama sekolah berpengaruh negatif atau berbanding terbalik dengan persentase penduduk miskin. Semakin tinggi rata-rata lama sekolah semakin kecil persentase penduduk miskin dan sebaliknya semakin rendah rata-rata lama sekolah semakin tinggi persentase penduduk miskin.

Pada kenyataannya, daerah-daerah dengan rata-rata lama sekolah rendah seperti Sampang, Bangkalan, Sumenep, Pamekasan, dan Kabupaten Probolinggo, merupakan daerah-daerah paling miskin. Daerah perkotaan seperti Kota Batu, Kota Malang, Kota Madiun, Kota Surabaya, dan Kota Mojokerto memiliki rata-rata lama sekolah yang tinggi 
dan tingkat kemiskinan yang rendah. Hubungan di atas terlihat sesuai dengan teori yang menyatakan bahwa pendidikan berkontribusi positif terhadap penurunan kemiskinan. Akan tetapi sebagaimana dijelaskan pada sebelumnya, hubungan ini dibangun oleh dua hubungan yang bertolak belakang dengan beberapa teori dan hasil penelitian sebelumnya: rata-rata lama sekolah berbanding terbalik dengan penyerapan tenaga kerja, penyerapan tenaga kerja yang berbanding lurus dengan persentase penduduk miskin.

Dengan demikian, hasil analisis statistik pengaruh rata-rata lama sekolah terhadap persentase penduduk miskin bertolak belakang dengan teori dan hasil penelitian yang menyatakan bahwa pendidikan mampu menurunkan tingkat kemiskinan melalui penyerapan tenaga kerja, sebagaimana temuan Nafziger (2006: 335) dan Cremin dan Nakabuko (2012). Namun hasil analisis ini lebih sesuai dengan temuan penelitian Gounder dan Xing (2012) di Fiji yang mempelajari aspek moneter dan nonmoneter dari pendidikan dan kesehatan. Penelitian terhadap aspek moneter menunjukkan bahwa pendidikan formal memang bermanfaat. Akan tetapi pendidikan formal ini tidak dapat mencegah orang yang hanya berpendidikan dasar jatuh ke dalam kemiskinan.

\section{Pengaruh Pertumbuhan Ekonomi Terhadap Penyerapan Tenaga Kerja}

Hasil analisis menunjukkan bahwa pertumbuhan ekonomi berpengaruh positif terhadap penyerapan tenaga kerja dengan koefisien pengaruh sebesar 0,167. Semakin tinggi pertumbuhan ekonomi, semakin tinggi pula tingkat penyerapan tenaga kerja. Berdasarkan uji hipotesis, pengaruh ini signifikan. Sebagian besar teori dan hasil penelitian mengungkapkan pengaruh positif pertumbuhan ekonomi terhadap penyerapan tenaga kerja. Okun (1962) dalam Sasana (2008:72) menunjukkan bahwa setiap laju pertumbuhan ekonomi sebesar 2,2 persen di atas tingkat trend yang dicapai pada tingkat tertentu, tenaga kerja terserap naik sebesar 1 persen. Akan tetapi Nallari dan Griffith (2011) memberikan catatan bahwa pertumbuhan ekonomi dapat meningkatkan penyerapan tenaga kerja secara optimal apabila pertumbuhan tersebut disumbang oleh sektor-sektor yang menyerap tenaga kerja. Catatan ini didukung oleh penelitian Balisacan dan Fuwa (2004) yang menganalisis proses pertumbuhan ekonomi dan pengurangan kemiskinan di Filipina selama tahun 1965-1995 relatif lebih buruk dibanding negara-negara tetangga di Asia Tenggara. Hasil penelitian menunjukkan bahwa rendahnya respon pengurangan kemiskinan terhadap pertumbuhan ekonomi adalah akibat rendahnya pertumbuhan di sektor pertanian. Hal ini mengingat pertanian merupakan sektor yang paling banyak menyerap tenaga kerja dibanding sektor industri.

\section{Pengaruh Pertumbuhan Ekonomi Terhadap Persentase Penduduk Miskin}

Berdasarkan model yang dikembangkan, pertumbuhan ekonomi mempengaruhi persentase penduduk miskin secara langsung dan tidak langsung. Secara langsung, 
pertumbuhan ekonomi berpengaruh negatif dan signifikan terhadap jumlah penduduk miskin dengan koefisien pengaruh sebesar $-0,263$. Secara tidak langsung, pertumbuhan ekonomi berpengaruh positif dan signifikan terhadap persentase penduduk miskin melalui variabel perantara penyerapan tenaga kerja dengan koefisien pengaruh tak langsung sebesar 0,070. Apabila kedua pengaruh digabungkan, maka pengaruh akhir variabel pertumbuhan ekonomi terhadap persentase penduduk miskin adalah sebesar 0,193 .

Secara tidak langsung, variabel pertumbuhan ekonomi berpengaruh positif terhadap variabel persentase penduduk miskin melalui penyerapan tenaga kerja. Sebagaimana uraian sebelumnya, penyerapan tenaga kerja sebagian besar terjadi pada sektor pertanian dengan tingkat penghasilan rendah dan tidak mampu membebaskan pekerja dari kemiskinan. Ferreira dkk. (2010) pernah meneliti faktor-faktor penyebab rendahnya kontribusi pertumbuhan ekonomi dalam menurunkan kemiskinan di Brasil. Selama periode 1985-2004, tingkat kemiskinan di Brasil hanya turun dari 33\% menjadi $29 \%$, sementara di negara berkembang lainnya turun drastis dari 33\% menjadi $18 \%$. Dengan membagi agregat PDB ke dalam beberapa wilayah dan sektor, penelitian ini menemukan bahwa efektifitas pertumbuhan ekonomi dalam menurunkan kemiskinan bervariasi di berbagai sektor, wilayah, dan waktu. Pertumbuhan sektor jasa ternyata lebih menurunkan kemiskinan dibandingkan sektor pertanian dan industri. Efektifitas pertumbuhan di sektor industri dalam menurunkan kemiskinan bervariasi menurut wilayah dan variasi ini berhubungan dengan kualitas SDM masing-masing wilayah. Penelitian Donaldson (2008) meneliti respon pengurangan kemiskinan terhadap pertumbuhan ekonomi. Penelitian ini menyimpulkan adanya faktor-faktor lain yang menyertai pertumbuhan ekonomi dalam mendorong pengurangan kemiskinan. Kebijakan redistribusi pendapatan, reformasi agraria, jaring pengaman sosial, dan pengurangan pengangguran adalah beberapa faktor yang menjadikan respon pengurangan kemiskinan terhadap pertumbuhan ekonomi menjadi lebih baik daripada yang diharapkan. Sementara ketiadaan faktor-faktor tersebut beserta tata kelola pemerintahan yang buruk, korupsi, dan bencana alam menjadikan respon pengurangan kemiskinan terhadap pertumbuhan ekonomi menjadi lebih buruk daripada yang diperkirakan.

\section{CONCLUSION}

Berdasarkan hasil penelitian dan pembahasan pada bab-bab sebelumnya, dapat diambil beberapa kesimpulan sebagai berikut:

1. Variabel rata-rata lama sekolah berpengaruh negatif secara signifikan terhadap penyerapan tenaga kerja. Hal ini tidak berarti bahwa pendidikan tidak dibutuhkan untuk meningkatkan penyerapan tenaga kerja, tetapi karena penyerapan tenaga kerja lebih banyak terjadi pada sektor pertanian yang relatif tidak membutuhkan pendidikan tinggi. 
2. Variabel penyerapan tenaga kerja berpengaruh positif secara signifikan terhadap persentase penduduk miskin. Hal ini tidak berarti bahwa penyerapan tenaga kerja mengakibatkan terjadinya kemiskinan, tetapi karena penyerapan tenaga kerja lebih banyak terjadi pada sektor pertanian dengan tingkat penghasilan yang rendah sehingga tidak mampu membebaskan tenaga kerja yang bekerja di sektor tersebut dari kemiskinan. Sementara tingkat penyerapan tenaga kerja pada sektor industri pengolahan dan sektor perdagangan, hotel, dan restoran relatif lebih rendah, meskipun tingkat penghasilannya tinggi.

3. Variabel pertumbuhan ekonomi berpengaruh positif secara signifikan terhadap variabel penyerapan tenaga kerja. Hal ini menunjukkan bahwa semakin tinggi pertumbuhan ekonomi semakin tinggi pula penyerapan tenaga kerja yang terjadi.

4. Variabel pertumbuhan ekonomi berpengaruh negatif signifikan terhadap variabel persentase penduduk miskin. Akan tetapi pertumbuhan ekonomi berpengaruh positif signifikan secara tidak langsung terhadap persentase penduduk miskin melalui penyerapan tenaga kerja. Hal ini karena penyerapan tenaga kerja lebih banyak terjadi pada sektor pertanian dengan tingkat penghasilan rendah dan tidak mampu membebaskan pekerja dari kemiskinan.

Berdasarkan pada kesimpulan yang telah diambil dari hasil penelitian, maka terdapat beberapa saran yang dapat dijadikan pertimbangan dalam upaya mengatasi dan menurunkan tingkat kemiskinan pada masing-masing kabupaten/kota di Provinsi Jawa Timur:

1. Sektor pertanian yang banyak menyerap tenaga kerja perlu mendapatkan prioritas dalam perencanaan dan pelaksanaan pembangunan, terutama dalam kerangka peningkatan dan perbaikan nilai tukar petani. Pembangunan jaringan irigasi, pemberian subsidi secara tepat, dan penerapan sistem tunda jual produk pertanian merupakan beberapa alternatif strategi yang dapat ditempuh.

2. Industri-industri pengolahan yang banyak menyerap tenaga kerja perlu dikembangkan dan mendapat perhatian khusus, terutama industri yang mengolah bahan baku lokal yang banyak disediakan oleh sektor pertanian.

3. Perlu dilakukan pemetaan terhadap kualitas dan spesifikasi pendidikan yang dibutuhkan lapangan kerja. Program link and match antara dunia kerja dan pendidikan perlu dipertimbangkan kembali, tidak hanya pada pendidikan tinggi tetapi juga pada pendidikan tingkat menengah.

\section{REFERENCES}

Arsyad, L. 2010. Ekonomi Pembangunan. Yogyakarta: UPP STIM YKPN.

Balisacan, A.M. dan N. Fuwa. 2004. Going beyond Crosscountry Averages: Growth, Inequality and Poverty Reduction in the Philippines. World Development. No.11 (Vol. 32): 1891-1907.

Bangwayo-Skeete, P.F., A.H. Rahim, dan P. Zikhali. 2011. Does education engender cultural values that matter for economic growth? The Journal of Socio-Economics. No.40: $163-171$. 
Boediono, 1995, Teori Pertumbuhan Ekonomi. Yogyakarta: BPFE, Universitas Gadjah Mada.

Bonal, X. 2007. On global absences: Reflections on the failings in the education and poverty relationship in Latin America. International Journal of Educational Development. No.27: 86-100.

BPS, 2007a, Analisis Indikator Makro Sosial dan Ekonomi Kabupaten/Kota Provinsi Jawa Timur.

Badan Pusat Statistik Jawa Timur.

-----, 2007b, Keadaan Angkatan Kerja di Propinsi Jawa Timur Agustus 2007. Badan Pusat Statistik Jawa Timur.

-----, 2008a, Analisis Indikator Makro Sosial dan Ekonomi Kabupaten/Kota Provinsi Jawa Timur. Badan Pusat Statistik Jawa Timur.

-----, 2008b, Provinsi Jawa Timur. Badan Pusat Statistik Jawa Timur.

-----, 2008c, Provinsi Jawa Timur dan Pemerintah Provinsi Jawa Timur. Badan Pusat Statistik Jawa Timur.

-----, 2008d, Keadaan Angkatan Kerja di Propinsi Jawa Timur Agustus 2008. Badan Pusat Statistik Jawa Timur.

-----, 2009a, Analisis Indikator Makro Sosial dan Ekonomi Kabupaten/Kota Provinsi Jawa Timur. Badan Pusat Statistik Jawa Timur.

-----, 2009b, Keadaan Angkatan Kerja di Propinsi Jawa Timur Agustus 2009. Badan Pusat Statistik Jawa Timur.

-----, 2010a, Analisis Indikator Makro Sosial dan Ekonomi Kabupaten/Kota Provinsi Jawa Timur. Badan Pusat Statistik Jawa Timur.

-----, 2010b, Keadaan Angkatan Kerja di Propinsi Jawa Timur Agustus 2010. Badan Pusat Statistik Jawa Timur.

-----, 2011a, Analisis Indikator Makro Sosial dan Ekonomi Kabupaten/Kota Provinsi Jawa Timur. Badan Pusat Statistik Jawa Timur.

------, 2011b, Provinsi Jawa Timur. Badan Pusat Statistik Jawa Timur.

------, 2011c, Keadaan Angkatan Kerja di Propinsi Jawa Timur Agustus 2011. Badan Pusat Statistik Jawa Timur.

------, 2012a, Produk Domestik Regional Bruto Provinsi Jawa Timur Kabupaten/Kota se Jawa Timur 2007-2011. Badan Pusat Statistik Jawa Timur.

------, 2012b, Data Makro Sosial Ekonomi Jawa Timur 2007-2011. Badan Pusat Statistik Jawa Timur.

-----, 2013a, Jawa Timur dalam Angka 2013. Badan Pusat Statistik Jawa Timur. 
-----, 2013b, Indikator Ekonomi dan Sosial Jawa Timur Tahun 2012. Badan Pusat Statistik Jawa Timur.

-----, 2013c, Statistik Upah 2012. Badan Pusat Statistik.

Cremin, P. dan M.G. Nakabuko. 2012. Education, development and poverty reduction: A literature critique. International Journal of Educational Development. No.32: 499 506.

Dahlin, Brian G. 2002. The Impact of Education on Economic Growth. Duke University.

Deliarnov, 2005, Perkembangan Pemikiran Ekonomi. Edisi Revisi, Jakarta: PT Raja Grafindo Prada.

Donaldson, J.A. 2008. Growth is Good for Whom, When, How? Economic Growth and Poverty Reduction in Exceptional Cases. World Development. No. 11 (Vol. 36): 2127-2143.

Dorantes, C.A. dan R.S. Padial. 2010. Labor market flexibility and poverty dynamics. Labour Economics. No.17: 632-642.

Dornbush, Rudiger and Fischer, Stanley, 1991. Macro Economics. Fourth Edition. New York: McGraw-Hill, Inc.

Ferreira, F.H.G., P.G. Leite, dan M. Ravallion. 2010. Poverty reduction without economic growth? Explaining Brazil's poverty dynamics, 1985-2004. Journal of Development Economics. No.93: 20-36.

Ganegodage, K.R., A.N. Rambaldi. 2011. The impact of education investment on Sri Lankan economic growth. Economics of Education Review. No.30: 1491-1502.

Gounder, R. dan Z. Xing. 2012. Impact of education and health on poverty reduction: Monetary and non-monetary evidence from Fiji. Economic Modelling. No.29: 787794.

Gujarati, Damodar, N., 2003, Basic Econometrics, New York: McGraw-Hill.

Hanushek, E.A. dan L. Wößmann. 2007. Education Quality and Economic Growth. Washington DC: The World Bank.

Herman, E. dan M.A. Georgescu. 2012. Employment strategy for poverty reduction. A Romanian perspective. Social and Behavioral Sciences. No.58: 406 - 415.

Irawan, Drs., M.B.A., dan Drs. M. Suparmoko M.A., Ph.D. 2002. Pembangunan Ekonomi, Edisi 6. Yogyakarta: BPFE.

Islam, R. 2004. The Nexus of Economic Growth, Employment and Poverty Reduction: An Empirical Analysis. Jenewa: Recovery and Reconstruction Department International Labour Office.

Published by University of Airlangga.

This is an open access article under the CC BY license (https://creativecommons.org/licenses/by-sa/4.0/) 
Jalil, A. dan M. Idress. 2013. Modeling the impact of education on the economic growth: Evidence from aggregated and disaggregated time series data of Pakistan. Economic Modelling. No.31: 383-388.

Jhingan, M.L., 2004, Ekonomi Pembangunan dan Perencanaan. Jakarta: Rajawali Press.

Kuepie, M., C.J. Nordman, dan F. Roubaud. 2009. Education and earnings in urban West Africa. Journal of Comparative Economics. No.37: 491-515.

Lleras, Christy. 2005. Encyclopedia of Social Measurement. Vol 3. Pennsylvania: Elsevier Inc.

Mankiw, N. G. 2007. Makroekonomi. Edisi 6. Terj. Jakarta: Penerbit Erlangga.

Nafziger, E.W. 2006, Economic Development. Edisi 4. New York: Cambridge University Press.

Nallari, R. dan B. Griffith. 2011. Understanding Growth and Poverty: Theory, Policy, and Empirics. Washington DC: The World Bank.

Peraturan Gubernur Nomor 38 Tahun 2009 tentang Rencana Pembangunan Jangka Menengah Daerah (RPJMD) Provinsi Jawa Timur Tahun 2009 - 2014.

Rollesto, C. 2011. Educational access and poverty reduction: The case of Ghana 1991 2006. International Journal of Educational Development. No.31: 338 - 349.

Simanjuntak, Payaman. J., 1998, Pengantar Ekonomi Sumber Daya Manusia, Jakarta: FEUI.

Sloman, J. 2006. Economics. $6^{\text {th }}$ Edition. London: Prentice Hall.

Stöterau, J. 2010. Estimating Growth Elasticities of Poverty. Berlin: Humboldt-Universität zu Berlin.

Sukirno, S. 2010. Makroekonomi: Teori Pengantar. Edisi 3. Jakarta: PT RajaGrafindo Persada.

Thirlwall, A.P. 2006. Growth \& Development with Special Reference to Developing Countries. Edisi ke-8. Palgrave Macmillan.

Todaro, M.P. dan S.C. Smith. 2006. Pembangunan Ekonomi. Edisi 9. Jilid 1. Terj. Jakarta: Penerbit Erlangga.

Undang-Undang Nomor 20 Tahun 2003 tentang Sistem Pendidikan Nasional

Van den Berg, H. 2005. Economic Growth and Development. New York: McGraw-Hill.

Zaman, K. dan B.A. Khilji. 2013.The relationship between growth and poverty in forecasting framework: Pakistan's future in the year 2035. Economic Modelling. No. 30: 468-491. 